\title{
WYKORZYSTANIE DOKUMENTU ELEKTRONICZNEGO W POSTĘPOWANIU ADMINISTRACYJNYM
}

\section{Wprowadzenie}

Administracja publiczna stanęła przed wyzwaniami związanymi z wprowadzeniem dokumentu elektronicznego wraz z wejściem w życie przepisów ustawy o informatyzacji działalności podmiotów realizujących zadania publiczne ${ }^{1}$ oraz ustawy o podpisie elektronicznym. ${ }^{2}$ Narzucone administracji przez ustawodawcę rozwiązania przez długi czas spotykały się z oporem urzędników, a także brakami finansowymi, co skutkowało przesuwaniem terminów realizacji projektów dotyczących elektronicznych dokumentów. ${ }^{3}$ Szczególnie dotkliwymi okazały się być problemy z dostosowaniem instrukcji kancelaryjnej do nowych standardów.

Jednym z pierwszych ośrodków, w którym podjęto się budowy nowoczesnej administracji opartej o dokument elektroniczny, był Podlaski Urząd Wojewódzki. We współpracy z Urzędem Marszałkowskim Województwa Podlaskiego rozpoczęto wprowadzanie wspólnego projektu administracji rządowej i samorządowej, umieszczając go w ramach Regionalnego Projektu Operacyjnego Województwa Podlaskiego na lata 2007-2013. ${ }^{4}$ Rozbudowa e-administracji w województwie podlaskim dostarczyła wielu cennych rozwiązań i informacji na temat problemów, jakie mogą rodzić oraz możliwych zastosowań nowoczesnych technologii w pracach urzędów.

W efekcie podjętych starań administracja publiczna przygotowana została do wykorzystania środków komunikacji elektronicznej. Przygotowania takiego zabrakło jednak w zakresie procedury administracyjnej. Sytuację tę miały zmienić zmiany

\footnotetext{
1 Ustawa z dnia 17 lutego 2005 r. o informatyzacji działalności podmiotów realizujących zadania publiczne (Dz.U. Nr 64, poz. 565 z późn. zm.), dalej jako: ustawa o informatyzacji.

2 Ustawa z dnia 18 września 2001 roku o podpisie elektronicznym (Dz.U. Nr 130, poz. 1450 z późn. zm.).

3 M. Madejczyk, Dokument elektroniczny w administracji publicznej. Wykorzystajmy szanse, „Elektroniczna Administracja” 2007, nr 4, s. 13; D. Chromicka, Dokumenty elektroniczne w urzędzie. Zastosowanie obowiązujących przepisów do instrukcji kancelaryjnej, „Elektroniczna Administracja” 2008, nr 5, s. 53. 
wprowadzone do tej gałęzi prawa przez ustawę z dnia 12 lutego 2010 r. o zmianie ustawy o informatyzacji działalności podmiotów realizujących zadania publiczne oraz niektórych innych ustaw (Dz. U. Nr 40, poz. 230). Niestety, okazuje się, że postępowanie administracyjne wymaga zmian głębszych oraz bardziej przemyślanych od tych, zaproponowanych przez ustawodawcę.

\section{Dokument a dokument elektroniczny}

Zdefiniowanie dokumentu elektronicznego, szczególnie w odniesieniu do tradycyjnego dokumentu, nie jest zadaniem prostym. Na pierwszy rzut oka oba wyżej wymienione pojęcia znacznie się od siebie różnią, jednak przy bliższej analizie okazuje się, że różnice te nie muszą wcale być aż tak odległe. Na wstępie należy jednak zaproponować pewne rozróżnienie pojęć „dokumentu” oraz „dokumentu tradycyjnego".

Dokładne wyjaśnienie zaproponowanego rozróżnienia należy rozpocząć od przedstawienia rozumienia drugiego z powołanych pojęć. Dokumentem tradycyjnym należy nazywać ,akt pisemny stanowiący wyrażenie określonych myśli lub wiadomości" 5 przy wykorzystaniu kartki papieru.

Pojęcie „dokumentu” jest pojęciem o wiele szerszym od przedstawionej powyżej interpretacji. W ujęciu cywilistycznym wskazuje się, że dokument jest „metodą skutecznego i trwałego przechowywania treści oświadczeń wiedzy lub oświadczeń woli". ${ }^{6}$ Powinien on składać się z trzech elementów: materiału, na którym został sporządzony, oświadczenia woli lub wiedzy oraz podpisu wystawcy. ${ }^{7}$ Jednocześnie wyróżnia się dokument sensu stricto (utrwalający wskazane wcześniej treści w formie pisemnej) oraz sensu largo (wyrażający jaką́s myśl przy wykorzystaniu innej techniki). ${ }^{8}$ Dokumentami drugiego typu mogą być np. mapy lub szkice. Mogą one stanowić dowód w sprawie, jednak odmawia się im cech dokumentu w sensie procesowym.

W ramach postępowania administracyjnego bardzo ważne zadanie spełnia rozróżnienie dokumentów urzędowych od dokumentów prywatnych. Art. $76 \S 1$ ustawy z dnia 14 czerwca $1960 \mathrm{r}$. Kodeks postępowania administracyjnego ${ }^{9}$ stwier- $^{-}$ dza, że „Dokumenty urzędowe sporządzone w przepisanej formie przez powołane do tego organy państwowe $\mathrm{w}$ ich zakresie działania stanowią dowód tego, co zostało w nich urzędowo stwierdzone”. Z przepisu tego wynika domniemanie „,zgodności z prawdą tego, co zostało w dokumencie stwierdzone przez organ, od którego

$5 \quad$ Cz. Martysz, Dowód z dokumentu w postępowaniu administracyjnym, [w:] Wokół problematyki dokumentu: księga pamiątkowa dedykowana Profesorowi Antoniemu Felusiowi, T. Widło (red.), Katowice 2005, s. 149.

6 E. Rudkowska-Ząbczyk, [w:] E. Marszałkowskiej-Krześ (red.), Postępowanie cywilne, Warszawa 2008, s. 184

7 S. Kotecka, Prawne aspekty nowych regulacji w obszarze dokumentu elektronicznego, „Elektroniczna Administracja" 2007, nr 2, s. 27.

8 E. Rudkowska-Ząbczyk, [w:] Postępowanie..., op. cit., s. 184

9 Tekst jedn. Dz.U. z 2000 r. Nr 98 z późn. zm., dalej jako: k.p.a. 
pochodzi”. ${ }^{10}$ Aby dokument mógł zostać uznany za urzędowy, musi spełniać dwa wymogi: wydanie przez uprawniony do tego organ (podmiot) oraz zachowanie odpowiedniej formy. ${ }^{11}$ Wymogi te mogą spełniać zarówno dokumenty w znaczeniu tradycyjnym, jak i dokumenty sporządzone w formie elektronicznej (o ile oczywiście taka forma będzie „formą przepisaną”). W obu tych przypadkach możliwe jest podpisanie sporządzonego dokumentu w sposób nie pozostawiający wątpliwości co do jego wystawcy.

\section{Czym jest dokument elektroniczny}

Definiować dokument elektroniczny (e-dokument) można z różnych punktów widzenia. Na początek warto przedstawić jego definicję informatyczną. Według niej dokumentem elektronicznym są ,dane, które zapisane są na dowolnym nośniku, przechowywane przy pomocy odpowiedniego oprogramowania, dające się odtworzyć, edytować, kopiować". ${ }^{12}$ Problem stanowi utożsamianie e-dokumentu z dokumentem komputerowym, co prowadzi do konkluzji, że każdy plik komputerowy jest dokumentem elektronicznym. Wydaje się jednak, że wyznacznikiem e-dokumentu powinna być przede wszystkim jego treść. W takim ujęciu nie wszystkie pliki zapisane w pamięci komputera staną się automatycznie dokumentami elektronicznymi, część zaś z dokumentów tradycyjnych może spełniać cechy e-dokumentu.

Definicję dokumentu elektronicznego zawiera ustawa o informatyzacji. Według przepisu art. 3 pkt 2 dokumentem elektronicznym jest ,stanowiący odrębną całość znaczeniową zbiór danych uporządkowanych w określonej strukturze wewnętrznej i zapisany na informatycznym nośniku danych". Informatycznym nośnikiem danych jest materiał lub urządzenie służące do zapisywania, przechowywania i odczytywania danych w postaci cyfrowej lub analogowej. ${ }^{13}$ Powyższa definicja podchodzi do problemu e-dokumentu od strony informatycznej. Podejściem prawnym wyróżnia się definicja dokumentu zawarta w kodeksie karnym przepis art. $115 \S 14$ ustawy z dnia 6 czerwca 1997 r. - Kodeks karny, według którego „Dokumentem jest każdy przedmiot lub zapis na komputerowym nośniku informacji, z którym jest związane określone prawo, albo który ze względu na zawartą w nim treść stanowi dowód prawa, stosunku prawnego lub okoliczności mającej znaczenie prawne”.

W praktyce dokumentem elektronicznym są informacje składające się na ,,plik komputerowy, zapisywany przy pomocy programu edytującego tekst, obraz lub

\footnotetext{
10 B. Adamiak, [w:] Kodeks postępowania administracyjnego. Komentarz, B. Adamiak, J. Borkowski, Warszawa 2012, s. 322.

11 Cz. Martysz, Dowód..., op. cit., s. 150.

12 M. Ganczar, Informatyzacja administracji publicznej. Nowa jakość usług publicznych dla obywateli i przedsiębiorców, Warszawa 2009, s. 68.

13 M. Ganczar, [w:] Kompendium wiedzy administratywisty, S. Wrzosek (red.), Lublin 2008, s. 614.
} 
dźwięk i odczytywany za pomocą właściwego urządzenia wyjścia". ${ }^{14}$ S. Kotecka $\mathrm{w}$ artykule Prawne aspekty nowych regulacji w obszarze dokumentu elektronicznego ${ }^{15}$ zauważa kilka problemów wiążących się z przywołaną powyżej definicją dokumentu elektronicznego zawartą w ustawie o informatyzacji. Autorka wskazuje na dość szerokie określenie przez ustawę znaczenia rozważanego terminu. Brak powołania wymogu opatrzenia e-dokumentu podpisem elektronicznym (lub innym środkiem technicznym zapewniającym jego autentyczność oraz niezmienność) może być uznane za niezapewniające wystarczającej pewności w trakcie korzystania z takiego dokumentu. Definicja nie wskazuje także, jaki jest status dokumentu elektronicznego w momencie jego przesyłania. Według niej, e-dokument powinien być „zapisany na informatycznym nośniku danych", co się jednak dzieje z chwilą przesłania go np. pocztą elektroniczną? Czy ujawnienie danych z dokumentu elektronicznego podczas jego transferu będzie niosło jakieś konsekwencje? Należy podkreślić, że jedną z cech e-dokumentu jest jego oddzielenie od nośnika, na jakim się znajduje (w przeciwieństwie do dokumentu tradycyjnego).

Pozostając $\mathrm{w}$ zgodzie $\mathrm{z}$ definicją zawartą $\mathrm{w}$ ustawie o informatyzacji można wskazać, że nawet zwykła kartka papieru, na której zapisano kod kreskowy możliwy do odczytania oraz zinterpretowania przez odpowiednie urządzenie, jest dokumentem elektronicznym, a zwykła kartka staje się w tym momencie ,informatycznym nośnikiem danych". ${ }^{16}$

Ciekawa wizja e-dokumentu zaprezentowana została w decyzji Komisji nr 2004/563/WE z 7 lipca 2004 r. zmieniającej jej regulamin wewnętrzny. ${ }^{17}$ Według jej art. 3 pkt 2 dokumentem elektronicznym jest ,zbiór danych wprowadzonych lub przechowywanych na dowolnym nośniku przez system informatyczny lub podobny układ, a także wszelkiego rodzaju prezentacja i wszelkiego rodzaju przedstawienie tych danych w formie drukowanej lub innej”. Z treści tej definicji wynika, że także wydruk komputerowy może być traktowany jako dokument elektroniczny.

Dane (w sensie informatycznym) zorganizowane w dokumentach mogą przyjmować przypadkową lub określoną (zdefiniowaną) strukturę fizyczną (format danych) i logiczną (zakres i układ danych). ${ }^{18}$ Zgodnie z tym mogą być odpowiednio niesformatowane lub sformatowane. Dokumentami elektronicznymi mogą być tylko takie zbiory danych, które zostały odpowiednio sformatowane. Dokument elektroniczny składa się z dwóch warstw: bitowej oraz interfejsowej. Pierwszą z nich jest „przechowywana w pamięci lub zapisana na nośniku sekwencja ładunków elektromagnetycznych, znana tylko maszynie i jako taka niedostępna człowiekowi bez

J. Janowski, Administracja elektroniczna: kształtowanie się informatycznego prawa administracyjnego i elektronicznego postępowania administracyjnego w Polsce, Warszawa 2009, s. 243.

S. Kotecka, Prawne aspekty..., op. cit., s. 26-38.

J. Janowski, Administracja elektroniczna..., op. cit., s. 251.

Dz. Urz. WE L 251 z dnia 27 lipca 2004 r., s. 9-13.

J. Janowski, Administracja elektroniczna..., op. cit., s. 243. 
przetworzenia”. ${ }^{19}$ Druga warstwa (interfejsowa) stanowi właśnie to ,przetworzenie", czyli graficzną interpretację warstwy bitowej.

\section{Przejawy wykorzystania dokumentu elektronicznego w postępowaniu administracyjnym}

Biorąc pod uwagę złożoność zagadnienia, jakim niewątpliwie jest wprowadzenie do postępowania administracyjnego elementów komunikacji elektronicznej, niemożliwe jest przedstawienie w tak krótkim opracowaniu wszystkich przejawów wykorzystania tych elementów. Wykorzystanie dokumentu elektronicznego wiąże się z różnorakimi instytucjami postępowania, takimi jak: doręczenia, dostęp do akt sprawy, wezwania, wnoszenie podań, czy też wydawanie decyzji. Poniżej przedstawione zostaną sztandarowe przykłady wykorzystania dokumentu elektronicznego w postępowaniu administracyjnym. Zagadnienia dokonywania doręczeń oraz wnoszenia podań niewątpliwie najlepiej oddają ducha wprowadzanych zmian, a także problemy, jakie z nimi się wiążą. Pokazują one także, że w celu faktycznego korzystania z nowoczesnych uregulowań prawnych niezbędna jest nie tylko prosta zamiana postulatów doktryny na przepisy prawne, ale przede wszystkim logika ich formułowania.

\section{Zmiana czy jej brak - zrównanie formy pisemnej z formą dokumentu elektronicznego}

$\mathrm{Na}$ wstępie rozważań dotyczących poszczególnych instytucji postępowania administracyjnego odwołujących się do elementów komunikacji elektronicznej wspomnieć należy o zmianie jednej z zasad ogólnych. Ustawodawca ustawą z dnia 12 lutego 2010 r. o zmianie ustawy o informatyzacji działalności podmiotów realizujących zadania publiczne oraz niektórych innych ustaw dokonał nowelizacji zasady ogólnej pisemności. Obok klasycznej formy załatwienia sprawy na drodze pisemnej wprowadzono możliwość załatwienia sprawy w drodze dokumentu elektronicznego. ${ }^{20}$

Chociaż działania ustawodawcy należy uznać za godne pochwały, zwrócić należy uwagę na problem, jaki wiąże się z dokonanym rozróżnieniem formy pisemnej od formy dokumentu elektronicznego. W efekcie doktryna stanęła przed problemem odpowiedzi na pytanie: czy forma dokumentu elektronicznego stanowi nową formę załatwienia sprawy, czy też jest pewnym podtypem formy pisemnej? Wydaje się, iż pismo może być utrwalone na różnych nośnikach informacji, w tym również

20 B. Adamiak, [w:] Kodeks..., op. cit., s. 83. 
na nośnikach elektronicznych. W praktyce więc utrwalenie „na piśmie” obejmuje swoim zakresem również formę dokumentu elektronicznego. ${ }^{21} \mathrm{Z}$ drugiej strony, ustawodawca dość konsekwentnie w treści poszczególnych przepisów Kodeksu postępowania administracyjnego odróżnia formę pisemną od formy dokumentu elektronicznego. W art. 61 k.p.a. ustawodawca odróżnia datę wszczęcia postępowania, w zależności od tego, czy żądanie wszczęcia postępowania zostało wniesione drogą elektroniczną, czy też nie. W art. 63 k.p.a. wyraźnie odróżnia się wymogi właściwe dla podania wnoszonego „pisemnie lub ustnie do protokołu” (art. $63 \S 3$ k.p.a.) od wnoszonego „W formie dokumentu elektronicznego" (art. $63 \S 3 \mathrm{a}$ k.p.a.). Może to prowadzić do wniosku, iż w postępowaniu administracyjnym mamy do czynienia $\mathrm{z}$ dwiema równorzędnymi i niezależnymi od siebie formami załatwienia sprawy. ${ }^{22}$ Powyższe wątpliwości mogą prowadzić do powstania wielu problemów praktycznych w związku z wykładnią poszczególnych przepisów Kodeksu postępowania administracyjnego. Większość doktryny na dzień dzisiejszy stoi na stanowisku, iż przepisy odnoszące się do formy pisemnej obejmują swoim zakresem również formę dokumentu elektronicznego, chyba że co innego wynika z „treści regulacji”. ${ }^{23}$

Należy zauważyć, iż art. 14 k.p.a. wyraźnie w swojej treści odwołuje się do pojęcia „dokumentu elektronicznego" odwołując się w zakresie jego definicji do ustawy o informatyzacji. Brak precyzji zawartej tam definicji wpływa na to, iż także w postępowaniu administracyjnym pojawić się mogą problemy z określeniem co powinno, a co nie powinno być kwalifikowane jako dokument elektroniczny. Szczególnego znaczenia nabiera to w związku ze szczegółowymi instytucjami postępowania administracyjnego.

\section{Doręczenia w formie elektronicznej}

$\mathrm{Z}$ doręczeniem mamy do czynienia, jeżeli organ (lub sąd) dostarcza stronie lub uczestnikowi postępowania jakieś dokumenty. Najważniejszym przepisem w kontekście doręczeń elektronicznych jest art. $39^{1}$ k.p.a. Określa on ścisłe ramy dla korzystania przez organ administracji publicznej z doręczania stronom pism przy wykorzystaniu środków komunikacji elektronicznej. Określone zostały dwa przypadki, w których skorzystanie z tego rodzaju doręczeń jest możliwe - żądanie strony lub jej zgoda w odpowiedzi na propozycję złożoną przez organ. Oznacza to, że nie ma możliwości korzystania z doręczeń elektronicznych w przypadku, gdy adres internetowy strony znany jest organowi, lecz strona nie wyraziła zgody na takie dorę-

Por. G. Szpor, Administracyjnoprawne problemy informatyzacji, [w:] J. Supernat (red.), Między tradycją a przyszłością w nauce prawa administracyjnego. Księga jubileuszowa dedykowana Profesorowi Janowi Bociowi, Wroclaw 2009, s. 721.

Por. A.G. Citko, Rewolucja czy ewolucja? Zmiany w postępowaniu administracyjnym i postępowaniu sądowo-administracyjnym, „Edukacja Prawnicza” 2010, nr 12 (120), s. 3.

23 P. Przybysz, Kodeks postępowania administracyjnego. Komentarz, Warszawa 2012, s. 74. 
czenie. ${ }^{24}$ Nie można również domniemywać takiej zgody z faktu wniesienia podania w formie elektronicznej. ${ }^{25}$ Nie można także uzależniać możliwości wniesienia podania w formie elektronicznej od wyrażenia wcześniej zgody na stosowanie doręczeń elektronicznych. ${ }^{26}$

Przepis art. $39^{1}$ k.p.a. wydaje się być przepisem niedostosowanym do wymogów dzisiejszego społeczeństwa oraz oczekiwań petenta. Celem jego wprowadzenia było przede wszystkim ułatwienie komunikacji na linii organ administracji publicznej - petent. W praktyce wzbudza on jednak wiele wątpliwości.

Zwrócić należy uwagę na paradoks, do jakiego dochodzi przy stosowaniu przepisu art. $39^{1}$ k.p.a.. Zgodnie z jego brzmieniem, jak wspomniano powyżej, organ administracji publicznej może zwrócić się do petenta o wyrażenie zgody na dokonywanie doręczeń w formie dokumentu elektronicznego. Organ nie może jednak wykorzystać do tego celów środków komunikacji elektronicznej. Zwrócenie się o wyrażenie zgody musi więc nastąpić w formie zwykłego pisma, aby można było uznać je za zgodne $\mathrm{z}$ prawem. ${ }^{27} \mathrm{~W}$ doktrynie pojawiło się co prawda stanowisko odmienne, w którym propaguje się odejście od wykładni literalnej na rzecz dopuszczenia przesłania środkami komunikacji elektronicznej pytania o zgodę na dokonywanie doręczeń w formie elektronicznej, ${ }^{28}$ uznać je jednak należy za niezgodne z wyraźną dyspozycją zawartą w przepisie.

Przepis art. $39^{1}$ k.p.a. nie daje podstaw do wyrażenia przez petenta zgody blankietowej, do dokonywania doręczeń przy wykorzystaniu dokumentów elektronicznych w przyszłych postępowaniach. Oznacza to, iż każdorazowo petent musi wyrażać odrębną zgodę, ewentualnie organ administracji publicznej musi występować o wyrażenie takiej zgody. ${ }^{29}$ Zgoda na doręczenia elektroniczne musi być jednoznaczna. ${ }^{30}$ Wydaje się, że może też ona być w każdym momencie cofnięta (tak samo jak żądanie). Chociaż nie zostało to uregulowane w k.p.a., należałoby uznać takie rozwiązanie za racjonalne. W końcu organ, w razie nieotrzymania potwierdzenia doręczenia elektronicznego, zobowiązany jest do doręczenia pisma w sposób tradycyjny. Cofnięcie zgody na doręczenia elektroniczne przez stronę pozwala organowi na zastosowanie od razu doręczenia tradycyjnego, co w efekcie doprowadzi do oszczędności czasu. ${ }^{31}$

\footnotetext{
24 J. Borkowski, [w:] Kodeks postępowania administracyjnego. Komentarz, B. Adamiak, J. Borkowski, Warszawa 2012, s. 302.

25 D. Szostek, e-Administracja - prawne zagadnienia informatyzacji administracji, Wrocław 2009, s. 77; G. Sibiga, Komunikacja elektroniczna w Kodeksie postępowania administracyjnego. Komentarz, Warszawa 2011, s. 65.

26 D. Szostek, e-Administracja..., op. cit., s. 77.

27 G. Sibiga, Komunikacja elektroniczna w Kodeksie postępowania administracyjnego. Komentarz, Warszawa 2011, s. 66.

28 R. Biskup, M. Ganczar, Komunikacja elektroniczna w postępowaniu administracyjnym, „Państwo i Prawo” 2008, nr 1, s. 67-68.

29 G. Sibiga, Komunikacja elektroniczna..., op. cit., s. 67.

30 D. Szostek, e-Administracja..., op. cit., s. 78.

31 Ibidem, s. 78.
} 
Każdorazowo także na organie administracji publicznej spoczywa obowiązek ustalenia adresu elektronicznego, na który dokonywane mają być doręczenia elektroniczne. Oznacza to, iż organ administracji publicznej w części przypadków zostanie zmuszony do wysłania odrębnego wezwania do podania takiego adresu. Problem może pojawić się w sytuacji, gdy petent adresu takiego nie poda pomimo zastosowanego wezwania. Jak wynika z art. $46 \S 3$ k.p.a., ustawodawca przewidział kolejność dokonywania doręczeń. Jeżeli petent wyraził zgodę lub wniósł o dokonywanie doręczeń w formie elektronicznej, nie ma możliwości doręczenia mu pism w formie tradycyjnej. W związku z powyższym, jeżeli organ administracji publicznej nie będzie mógł uzyskać adresu elektronicznego petenta, nie będzie mógł dokonywać skutecznych doręczeń. Przepisy prawa nie przewidują żadnej sankcji za niepodanie adresu elektronicznego, w związku z czym organ administracji publicznej nie będzie dysponował możliwością zmuszenia petenta do wskazania adresu elektronicznego do doręczeń. $\mathrm{W}$ takim przypadku jedynym wyjściem byłoby zakwalifikowanie braku adresu elektronicznego jako braku nieusuwalnego podania.

Należy zauważyć, iż w ramach toczącego się postępowania może dojść do sytuacji, w której część doręczeń dokonywana będzie przy pomocy tradycyjnej formy pisemnej, część zaś przy wykorzystaniu dokumentu elektronicznego. Część uczestników postępowania może wyrazić zgodę na dokonywanie doręczeń w formie elektronicznej, część zaś może nie skorzystać z takiej możliwości. Organ administracji publicznej będzie więc posiadał dokumenty o takiej samej treści sporządzone w tradycyjnej formie pisemnej oraz w formie elektronicznej. ,Z procesowego punktu widzenia będzie to ten sam dokument, którego egzemplarze funkcjonują na różnych nośnikach (papierowych i elektronicznych)". ${ }^{32}$

\section{Wniesienie podania przy wykorzystaniu dokumentu elektronicznego}

Nowelizacja z dnia 12 lutego 2010 r. rozszerzyła wykorzystanie środków elektronicznych umożliwiających wniesienie podania. Jedynym wymogiem wobec podań wnoszonych przy wykorzystaniu środków elektronicznych jest wniesienie ich za pośrednictwem skrzynki podawczej organu administracji publicznej utworzonej na podstawie ustawy z dnia 17 lutego 2005 r. o informatyzacji działalności podmiotów realizujących zadania publiczne.

Wyżej przedstawiony wymóg sprawia, iż pismo wniesione na inny adres elektroniczny niż adres elektronicznej skrzynki podawczej w ogóle nie będzie mogło być zakwalifikowane jako podanie. Co więcej, organ nie będzie mógł wezwać wnoszącego do uzupełnienia braków formalnych. „Wymóg korzystania z ESP [elek- 
troniczna skrzynka podawcza - przyp. A.C.] znajduje się bowiem w przepisie dotyczącym sposobów składania podania, a nie warunków formalnych podania." ${ }^{33}$ Wydaje się, iż w takiej sytuacji organ administracji publicznej powinien poinformować wnoszącego o nieskutecznym wniesieniu podania, jednak taki obowiązek nie został na niego nałożony przez przepisy prawa.

Zgodnie $\mathrm{z}$ wymogiem art. $63 \S 3 \mathrm{a}$ pkt 2 k.p.a. podanie wniesione $\mathrm{w}$ formie dokumentu elektronicznego musi zawierać dane w ustalonym formacie, zawarte we wzorze podania określonym przez odrębne przepisy, jeżeli nakazują one wnoszenie podań według wzoru. Jeżeli taki wzór nie jest wymagany, wystarczy, gdy podanie spełnia warunki określone w art. $63 \S 2$ k.p.a. oraz przepisach odrębnych. ${ }^{34}$

Podanie wnoszone w formie elektronicznej powinno wskazywać osobę, od której pochodzi, jej adres oraz żądanie, a także czynić zadość wymaganiom ustalonym w przepisach szczególnych. Wady podania można podzielić na usuwalne i nieusuwalne. Wada zostanie zakwalifikowana jako usuwalna, jeżeli z wnoszącym podanie można się w jakikolwiek sposób skomunikować. ${ }^{35}$ Jeżeli w podaniu widnieje adres wnoszącego, może on zostać „wezwany do sprecyzowania żądania, dołączenia dokumentów, złożenia wyjaśnień, do uiszczenia wymaganych opłat i opłacenia z góry kosztów postępowania". ${ }^{36}$ Razem z wezwaniem wyznacza się termin do usunięcia braków formalnych. Został on określony w art. $65 \S 2$ k.p.a. i wynosi 7 dni. W przypadku upłynięcia tego terminu, jeżeli wnoszący nie zabiegał o jego przedłużenie, podanie pozostawia się bez rozpoznania. ${ }^{37}$ Podanie pozostawia się także bez rozpoznania, jeżeli dotknięte jest ono brakami nieusuwalnymi. Jedynym brakiem formalnym uzasadniającym pozostawienie podania bez rozpoznania jest brak adresu wnoszącego. Niewskazanie adresu skutkuje brakiem możliwości indywidualizacji strony, bez czego nie może być prowadzone postępowanie..$^{38}$

W odniesieniu do wniesienia podania w formie elektronicznej należy zastanowić się nad dwoma problemami: wniesienia podania w formie tradycyjnej z podaniem jedynie adresu elektronicznego oraz wniesienia podania w formie elektronicznej bez podania adresu elektronicznego.

W pierwszym z wyżej wskazanych przypadków problem stanowi definicja pojęcia „adresu”. Wydaje się, że ustawodawca rozumie go w sposób tradycyjny, umożliwiający kontakt przy pomocy tradycyjnego dokumentu. Podanie adresu elektronicznego nie oznaczałoby więc, iż mamy do czynienia $\mathrm{z}$ wadami usuwalnymi podania. Pewnej furtki umożliwiającej obejście takiego rozumowania można do-

Ibidem, s. 105.

M. Ganczar, Informatyzacja administracji publicznej, op. cit., s. 83.

W. Chróścielewski, J.P. Tarno, Postępowanie administracyjne i postępowanie przed sądami administracyjnymi, Warszawa 2009, s. 116.

36 J. Borkowski, [w:] Postępowanie administracyjne i sądowo-administracyjne, B. Adamiak, J. Borkowski, Warszawa 2009, s. 177.

$37 \quad$ Ibidem.

38 B. Adamiak, [w:] Kodeks..., op. cit., s. 374. 
szukiwać się w art. $64 \S 1$ k.p.a., w którym ustawodawca wspomina, iż z brakiem nieusuwalnym podania mamy do czynienia, gdy nie ma możliwości ustalenia adresu wnoszącego na podstawie posiadanych danych. Wydaje się, iż adres poczty elektronicznej można byłoby wykorzystać jako właśnie ,posiadane dane”. Zwrócić jednak należy uwagę na rygorystyczne podejście ustawodawcy do dokonywania doręczeń przy pomocy środków elektronicznych. Zgodnie z opisywanym już art. $39^{1}$ k.p.a. dokonanie doręczenia elektronicznego możliwe jest jedynie za zgodą lub na wniosek petenta. Skierowanie przez organ administracji publicznej wezwania do uzupełnienia braków formalnych na adres poczty elektronicznej w przedstawionym przypadku byłoby więc niezgodne z tym uregulowaniem.

$\mathrm{W}$ drugim z rozpatrywanych przypadków niewskazanie przez petenta adresu poczty elektronicznej skutkowałoby obowiązkiem dokonywania doręczeń w tradycyjnej formie pisemnej. Organ administracji publicznej musiałby wystąpić do petenta z prośbą o wskazanie adresu elektronicznego. Co więcej, w przypadku gdyby co prawda petent wskazał adres poczty elektronicznej, bez wskazania jednak, iż na ten adres żąda dokonywania doręczeń elektronicznych, organ administracji publicznej powinien zwrócić się do niego o doprecyzowanie złożonego wniosku. Powyższa sytuacja opiera się na założeniu, iż organ administracji publicznej co prawda dysponuje adresem poczty elektronicznej petenta, nie ma jednak pewności co do tego, czy na ten właśnie adres powinien dokonywać doręczeń elektronicznych.

\section{Dokument elektroniczny a zasada zrównoważonego rozwoju}

Zagadnienie „zrównoważonego rozwoju” najlepiej definiuje pierwsze zdanie raportu Światowej Komisji ds. Środowiska i Rozwoju z 1987 r.: „Na obecnym poziomie cywilizacyjnym możliwy jest rozwój zrównoważony, to jest taki rozwój, w którym potrzeby obecnego pokolenia mogą być zaspokojone bez umniejszania szans przyszłych pokoleń na ich zaspokojenie." ${ }^{39}$ Niewątpliwie, wykorzystanie środków komunikacji elektronicznej w ramach postępowania administracyjnego wpływa na realizację idei zrównoważonego rozwoju. Uniknięcie nadmiernej biurokratyzacji oraz rezygnacja $z$ tradycyjnej formy pisemnej daje szansę rozwoju społecznego oraz ochrony środowiska naturalnego. Niestety, wprowadzane przez ustawodawcę zmiany często prowadzą do sytuacji, w których organy administracji publicznej zmuszone są działać w sposób nieracjonalny. W efekcie wielu obostrzeń oraz wymogów zarówno petentom, jak i organom administracji publicznej dużo łatwiej jest korzystać z tradycyjnych metod komunikacji, niż wykorzystywać w tym celu dokumenty elektroniczne. Wydaje się, iż administracja publiczna powinna sama również realizować zasady zrównoważonego rozwoju, nie zaś jedynie zajmować się regulacją oraz kontrolą nad przestrzeganiem tej zasady przez podmioty trzecie. 
Należy podkreślić, iż samo teoretyczne oraz techniczne przygotowanie administracji publicznej do wykorzystywania dokumentu elektronicznego w postępowaniu administracyjnym nie wystarczy dla rozwoju idei e-administracji. Praktyczne wykorzystanie związanych z nią instytucji stanie się jednak możliwe dopiero w momencie, w którym regulacja ich dotycząca przestanie prowadzić do licznych paradoksów, zaś skorzystanie z nich faktycznie prowadzić będzie do oszczędności czasu, nie zaś sztucznego wywoływania kolejnych problemów. Zadaniem ustawodawcy jest stanowienie mądrego prawa, prawa, które nie tylko będzie dobrze brzmiało, ale przede wszystkim będzie spełniało swoją rolę. Celem wprowadzenia elementów komunikacji elektronicznej do postępowania administracyjnego jest odejście od tradycyjnego dokumentu, oszczędność czasu i środków. Niestety, na dzień dzisiejszy nadal stanowi to odległą przyszłość, która stoi pod znakiem kolejnych niezbędnych nowelizacji prawa.

\section{BIBLIOGRAFIA}

Adamiak B., Borkowski J., Kodeks postępowania administracyjnego. Komentarz, Warszawa 2012.

Adamiak B., Borkowski J., Postępowanie administracyjne i sądowo-administracyjne, Warszawa 2009.

Biskup R., Ganczar M., Komunikacja elektroniczna w postępowaniu administracyjnym, „Państwo i Prawo" 2008, nr 1.

Chromicka D., Dokumenty elektroniczne w urzędzie. Zastosowanie obowiązujących przepisów do instrukcji kancelaryjnej, „Elektroniczna Administracja” 2008, nr 5.

Chróścielewski W., Tarno J.P., Postępowanie administracyjne i postępowanie przed sądami administracyjnymi, Warszawa 2009.

Citko A.G., Rewolucja czy ewolucja? Zmiany w postępowaniu administracyjnym i postępowaniu sądowo-administracyjnym, „Edukacja Prawnicza” 2010, nr 12 (120).

Ganczar M., Informatyzacja administracji publicznej. Nowa jakość usług publicznych dla obywateli i przedsiębiorców, Warszawa 2009.

Janowski J., Administracja elektroniczna: kształtowanie się informatycznego prawa administracyjnego i elektronicznego postępowania administracyjnego w Polsce, Warszawa 2009.

Kotecka S., Prawne aspekty nowych regulacji w obszarze dokumentu elektronicznego, „Elektroniczna Administracja" 2007, nr 2.

Madejczyk M., Dokument elektroniczny w administracji publicznej. Wykorzystajmy szansę, „Elektroniczna Administracja” 2007, nr 4.

Marszałkowska-Krześ E. (red.), Postępowanie cywilne, Warszawa 2008.

Przybysz P., Kodeks postępowania administracyjnego. Komentarz, Warszawa 2012.

Sibiga G., Komunikacja elektroniczna w Kodeksie postępowania administracyjnego. Komentarz, Warszawa 2011.

Supernat J. (red.), Między tradycją a przyszłością w nauce prawa administracyjnego. Księga jubileuszowa dedykowana Profesorowi Janowi Bociowi, Wrocław 2009. 


\section{Adam Citko}

Szostek D., e-Administracja - prawne zagadnienia informatyzacji administracji, Wrocław 2009.

Widło T. (red.), Wokół problematyki dokumentu: księga pamiątkowa dedykowana Profesorowi Antoniemu Felusiowi, Katowice 2005.

Wrzosek S. (red.), Kompendium wiedzy administratywisty, Lublin 2008. 


\section{THE USE OF ELECTRONIC DOCUMENTS IN THE ADMINISTRATIVE PROCEDURE}

This article discusses the institution of an electronic document (e-document) and its use by the public administration. Subjects of a detailed analysis become institutions of delivery and bringing of an application with the help of an e-document. This article indicates the practical importance of an e-document and its possible use in the administrative procedure. The summary indicates the importance of an electronic document to the principle of sustainable development.

Keywords: administrative procedure, general principles, electronic document, principle of sustainable development, general principle of written form 